\title{
Making Fitness to Plead Fit for Purpose
}

\author{
Amar Shah*
}

Specialist Registrar in Forensic Psychiatry, East London NHS Foundation Trust, East One, 22 Commercial Street, London E1 6LP, UK

\begin{abstract}
In the England and Wales criminal justice system, consideration of a defendant's ability to stand trial is known as 'fitness to plead'. No accused person may face trial unless they are fit to plead to the charges against them. The fitness to plead criteria date back to the $19^{\text {th }}$ century, and have been virtually unchanged. Developed from case law relating to sensory impairment and intellectual disability, they are now routinely utilised for severe and enduring mental illnesses, predominantly psychotic disorders. The fitness to plead criteria are no longer appropriate to meet modern understanding of complex mental disorders, and are shamefully archaic in comparison to civil capacity legislation. This paper outlines the development of the fitness to plead criteria and process, summarises current criticisms and proposes potential reform in this fundamental area of mental health law.
\end{abstract}

Keywords: Fitness, competence, mental health, law, criminal justice, psychiatry.

\section{INTRODUCTION}

In the England and Wales criminal justice system, consideration of a defendant's ability to stand trial is known as 'fitness to plead'. No accused person may face trial unless they are fit to plead to the charges against them. This fundamental concept is concerned with the defendant's mental state at the time of trial, as opposed to what it may have been at the time of the alleged offence. As Lord Bingham stated in $\mathrm{R} \vee \mathrm{H}$ (2003), "Over the last two decades, statute law in England and Wales has recognised and addressed, with growing sophistication and particularity, two allied but different problems. One of those problems arises where it appears that a person accused of committing a serious crime was, or may have been, in such a mental state at the time of committing it as to render him irresponsible, in the eyes of the law, for what he is said to have done. The second problem arises where it appears that a person accused of committing a serious crime, whatever his mental state at the time of committing it, is or may at the time of his trial be in such a mental state as to render him unfit to be tried."

Fitness to stand trial, the second of the problems articulated by Lord Bingham above, is grounded in common law, which held that it is unfair to bring to trial an individual who is not able to participate fully in, or understand, the judicial proceedings. As stated in $\mathrm{R} v$ Podola (1960), "no man may be brought to trial upon any criminal charge unless and until he is mentally capable of fairly standing his trial". It has been a fundamental principle of natural justice that someone

*Address corresponding to this author at the East London NHS Foundation Trust, East One, 22 Commercial Street, London E1 6LP, UK; Tel: +44 (0)7961 390112; E-mail: amar.shah245@gmail.com accused of a crime has a right to a fair and impartial trial. That the accused be fit to plead and fit to stand trial is based on the recognition that it is unfair to try an unfit accused, and inhumane to subject an unfit accused to trial and punishment, with the rationale that an accused individual must be protected from a conviction that could have resulted from lack of capacity to participate and make proper judgments. There is also a desire for the mentally disordered to receive treatment, not punishment. The principle of fitness to plead is also based on concern to preserve the moral dignity of the trial process and avoid inaccuracy in the criminal adjudication process (Bonnie 1993). The trial of an unfit accused is perceived comparably to trial of an accused in absentia (Allen, Kesavarajah and Moses 1993).

Certain rules have come to be recognised in dealing with those unfit to plead, as described by Lord Bingham in $\mathrm{R} v \mathrm{H}$ (2003). Firstly, that those found unfit to plead should not stand trial in the same way as a defendant who is fit to plead. Secondly, that a trial procedure was necessary to determine whether an accused person was fit to stand trial. Thirdly, that these issues were appropriate to be determined by a jury, subject to the direction of a judge. Fourth, that even though a person may be found unfit to stand trial in the ordinary way, such person may nonetheless represent a continued threat to members of the public such that, in the interest of public safety, the detention of such person may be justified.

The decision regarding fitness to plead is ultimately for the court, but the court depends significantly upon expert assessments provided by psychiatrists and psychologists. The role and involvement of medical evidence is of key importance, with high rates of 
agreement between evidence from mental health professionals and court determinations. Assessment of fitness to plead is a consideration for any psychiatrist who is asked to examine someone facing criminal charges. Nevertheless, it has been clearly stated that the decision itself is "not for medical men of whatever eminence" ( $R \vee$ Rivett 1950), leaving expert witnesses to tread a fine line.

Although opinion is provided mostly by medical professionals, the criteria upon which the decision is made are legal. The criteria for assessing fitness to plead have been a contentious and difficult issue for the law over many decades. By its nature, fitness to plead is a threshold issue, determining whether the defendant should remain within the criminal justice system or be diverted to the health service. The translation from a dimensional view of disorder and symptoms to a unitary construct has led to much criticism. The greatest challenge has been to balance fair and humane treatment of an accused person with protection of the public against the risk of danger posed by someone who cannot be tried in the ordinary way to determine guilt.

This article will commence with an outline of the origins and historical development of the fitness to plead concept, before considering how the legal criteria and procedure have been modified by legislation and case law. I will then compare this with arrangements in the Magistrates (lower) courts, as well as similar arrangements in other jurisdictions internationally. Finally, I will consider the existing research base in this field, critically analyse the current fitness to plead criteria and procedure, and suggest recommendations for reform in this area.

\section{HISTORICAL ORIGINS}

The development of the concept of fitness to plead can be traced to antecedents and procedural formalities in medieval England. However, even in preNorman England, there was provision in the legal system for the mentally abnormal. During this period, different localities had diverse customs and separate court systems. In several jurisdictions, such as $7^{\text {th }}$ century Northumbria and Kent, crime was a matter for compensation for loss of property, injury or life, rather than for formal trial and sentence. A text by Egbert, Archbishop of York in the $8^{\text {th }}$ century, referring to the procedure for the insane, states "If a man fall out of his senses or wits, and it come to pass that he kill someone, let his kinsmen pay for the victim" (Walker 1968).
At this time, the concept of intent, responsibility or mens rea were irrelevant, with the principal concern being committal of the act. By the time of the Norman conquest, certain crimes such as murder, arson, adultery and treachery against one's lord had become public wrongs, requiring punishment by death or mutilation and seizure of the offender's property by the Crown. Compensation was no longer sufficient. Guilt was determined through trial by ordeal involving the Deity. For a slave, trial by ordeal meant placing a bandaged hand into boiling water, with guilt being determined by the presence of scalding after three days. For the freeman, trial by ordeal involved walking over red-hot ploughshares without being scarred, putting one's hand into a glove of hot iron or picking up a hot iron bar, with presence of blisters after three days being a sign of guilt.

Actus reus remained of prime importance, although intent was becoming increasingly relevant. Determination of guilt progressed by the $11^{\text {th }}$ century from compurgation (with witnesses swearing to the good character and innocence of the accused) and trial by combat, to formal King's Courts. In the $12^{\text {th }}$ century, during the reign of Henry II, trials were conducted for serious offences by travelling justices, with a system of prosecution by the Crown. This, however, brought mentally abnormal offenders into the realm of the Court whereas previously they may have been confined in prison or released to the protection of their families. Once the jury had certified the facts, the King decided what should be done with the insane offender, as only the King could interfere with the normal course of the law and excuse the accused from the automatic penalty for the felony.

In 1583, Somervile attacked a number of people with his sword, based on the belief that he had to shoot the Queen to protect Catholicism from persecution. He entered no plea to the Court. The justices had to decide whether his silence was caused by real or feigned madness, and held an "inquest of office" in which twelve jurors would decide if Somervile's madness was genuine. The outcome is not clear, although it appears that Somervile later pleaded guilty and was sentenced to beheading, although was found dead in his cell before the sentence could be carried out. This appears to be the first recorded example of a jury being empanelled to decide on the question of insanity pre-trial. The procedure was modelled on the civil inquests that were held to decide whether a person was mentally competent to handle their own affairs. 
The adversarial process in Court could not begin until the accused entered a meaningful plea. The accused were not considered to be tried properly unless they consented to their trial by "pleading and putting themselves on the country" (Hale 1971). Once the indictment had been read, the accused was asked, "How say you: guilty or non-guilty?" If he replied, "Nonguilty", he was then asked, "How will you be tried?" The accused had to answer "By God and my country". If an individual did not comply with this ritualistic start to the trial, the smooth running of the legal process was brought to a jarring halt. In addition, without a trial and determination of guilt, the Crown could not expropriate the property of the offender.

If the accused refused to answer these questions, he was said to "stand mute" and a jury was sworn to try whether he was "mute of malice" or "mute by the visitation of God". If the accused was found to be mute of malice, the Court gave three warnings, after which the accused was subjected to the "prison forte et dure", being confined in a narrow cell and starved until he either reconsidered their position or died. From 1406, the withholding of food was replaced by the "peine forte et dure", in which the mute defendant was both starved and gradually crushed under increasing weights, until he was dead or had agreed to enter a plea. The usual underlying motivation behind intentionally not entering a plea (ie. being mute of malice) was to preserve the accused man's property for his family and avoiding the forfeiture to the Crown which followed conviction. By not entering a plea, there could be no trial, no conviction and hence no forfeiture. Of interest, the challenging of 36 jurors was held to constitute a finding of mute of malice (Higson 1936).

The last case of pressing was in 1726, when a man accused of murder was pressed for two hours, before pleading not guilty. He was later tried, convicted and hanged. The law and procedure remained unchanged until 1772, when standing mute of malice in cases of felony was made equivalent to a conviction.

If however the accused was found to be "mute by the visitation of God", he was spared the peine forte et dure, and a plea of not guilty was entered on his behalf. However, the Courts often first attempted to persuade the accused to plead by tying his thumbs together with whipcord (Hale 1971). Mute by visitation of God was used in cases where the defendant was deaf-mute, insane or learning disabled. As those with hearing and speech disorders (termed deaf-mutes in early references) received little training in communication, they would have appeared intellectually disabled to the Courts of the $18^{\text {th }}$ and $19^{\text {th }}$ century, and would have been treated similarly to the learning disabled (referred to as "idiots" or "natural fools" at that time) and mentally disordered (referred to as "lunatics"). Once a not guilty plea was entered on behalf of someone mute by visitation of God, someone who was able to communicate with the defendant was asked to assist the Court. A two-step process was required. First, a decision about the cause of muteness, and following a finding of mute by visitation of God, a decision about whether the defendant was of sufficient intelligence to undergo trial.

Hale, ${ }^{1}$ who deeply influenced this aspect of the law in the $18^{\text {th }}$ and $19^{\text {th }}$ centuries, stated clearly that trial should be postponed in the case of the insane. For capital offences, which included a long list of felonies, Hale suggested that the insane defendant be "remitted to prison until that incapacity is removed; the reason is, because he cannot advisedly plead to the indictment" (Hale 1971). However, Hale alluded to the requirement for the defendant being "absolutely mad", suggesting a high threshold of insanity. A law passed during the reign of Henry VIII made treason a special exception to this rule, stating that if anyone committed high treason while "in good, whole and perfect memory" and then became "non compos mentis", they were still to be tried and dealt with. This was repealed by statute shortly after, in the reign of Queen Mary.

Hale also wrote that the trial of a deaf-mute could continue as long as the Court exercised care that the defendant was not mentally defective (Hale 1971). Therefore, being mute by visitation of God was not an absolute bar to trial. Cases such as $\mathrm{R} v$ Thomas Jones (1773) and R $\vee$ Steel (1787) set the precedent. Steel entered no plea, and was found mute by the visitation of God. After some months of doubt about what to do, it was decided, based on Hale's authority, that the presumption of idiotism "may be repelled" in her case and that she could be tried. She was found guilty and sentenced to seven years transportation.

The trial of Hadfield, who attempted to assassinate King George III in Drury Lane theatre, led to the Criminal Lunatics Act in 1800. Hadfield was a private in

\footnotetext{
${ }^{1}$ Sir Matthew Hale (1609-1676) was an English lawyer of eminence during the reigns of Charles I, Cromwell and Charles II. He was a great scholar of the history of English common law, was well known for his judicial impartiality during the English Civil War, and played a major role in the law reform proposals of the Convention Parliament and in promoting Charles II's restoration.
} 
the army who had received several sabre wounds to the head and had been discharged from the army due to insanity, after suffering from delusions and attacks of maniacal frenzy. When this evidence was presented in Court, Hadfield was acquitted as insane. Public opinion demanded that an alternative disposal and procedure be adopted for such cases. The Criminal Lunatics Act stated "that if any person indicted for any offence shall be insane, and shall on arraignment be found so to be, by a jury lawfully impanelled for that purpose, so that such person cannot be tried upon such indictment, it shall be lawful for the Court to direct such finding to be recorded, and thereupon to order such person to be kept in strict custody until His Majesty's pleasure shall be known". This statute provided much-needed clarity to the law, allowing those unfit for trial, whether as a result of deafness, mental defect or insanity, to be found legally insane and given an indeterminate detention. However, the effect of this statute was that this cohort of insane defendants was distributed among the county goals and asylums, where the conditions of security were so inadequate that many escaped.

It was only in 1827 that a plea of not guilty was also entered for those standing mute of malice, as well as those mute by visitation of God. An Act of George IV stated that if a person be found on arraignment to be mute of malice, being charged with either treason, felony, or misdemeanour, then the Court shall have a discretionary power to enter a plea of not guilty, and that entering this plea shall have the same efficacy and effect as if it was entered by the accused himself.

\section{EARLY CASE LAW}

The case of Dyle in 1756 represents perhaps the earliest recognition of the modern form of unfitness to plead. Dyle was accused of murder, but his lawyer was unable to take instructions from him and told the Court "I don't think he is capable of attending to or minding the evidence, or remembering it when he has heard it" (Walker 1968). The jury found Dyle "not of sound mind and memory", and he was not tried.

In 1790, Frith threw a stone at a coach in which George III was riding, and was subsequently arrested for high treason. He was found to be insane, presenting as overinclusive, grandiose and paranoid, but objected to his trial being postponed. A jury was empanelled to determine whether he was "in a fit situation to plead". Lord Chief Justice Kenyon told the jury "No man shall be called upon to make his defence at a time when his mind is in that situation as not to appear capable of so doing". Frith was found insane, and "remanded for the present".

The test for fitness to plead evolved from common law, but the specific criteria for fitness to plead emerged during the $19^{\text {th }}$ century in the form of case law. In the 1830 trial at the York Spring Assizes of Esther Dyson, a 'deaf and dumb' woman was indicted for murdering her illegitimate child by cutting of its head ( $R \vee$ Dyson 1831). A sign language interpreter said that it was impossible to make Ms Dyson understand that she could object to members of the jury. Mr Justice Parke, after consulting Hale's "Pleas of the Crown" (Hale 1971), directed the jury that "if they were satisfied that the prisoner had not then, from the defect of her faculties, intelligence enough to understand the nature of the proceedings against her, they ought to find her insane". Ms Dyson was found to be insane, and detained indefinitely, under the Criminal Lunatics Act (1800), until His Majesty's pleasure was known (Higson 1936).

This decision was in turn further clarified in $\mathrm{R} v$ Pritchard (1836), which continues to form the basis of the common law criteria for fitness to plead. Pritchard, who was also 'deaf and dumb' was indicted for the capital offence of bestiality. Baron Alderson put three distinct issues to the jury, directing the jury to be sworn separately on each; firstly, whether the prisoner was mute of malice or by the visitation of God; secondly, whether he was able to plead; and thirdly, whether he was sane or not. On the last issue the jury were directed to inquire "whether (the defendant) was of sufficient intellect to comprehend the course of the proceedings of the trial, so as to make a proper defence - to know that he might challenge [any jurors] to whom he may object - and to comprehend the details of the evidence, which in the case of this nature must constitute a minute investigation. It is not enough that he may have a general capacity of communicating on ordinary matters". The jury were directed that if there was no certain mode of communicating to the prisoner the details of the evidence so that he could clearly understand them and be able properly to make his defence to the charge against him, the jury ought to find that he was not of sane mind. Based on this direction, Pritchard was found "not capable of taking his trial", and was ordered to be confined in prison.

Although the direction refers to being "not of sane mind", the term insanity during this period would have included both of what is now known as mental impairment and mental illness, with no distinction 
drawn between learning disability, physical or mental illness. It is, however, different from the legal concept of insanity as set out in the later M'Naghten Rules.

The test as defined in $\mathrm{R} \vee$ Pritchard (1836), which remains in force today, is therefore explicitly an intellectual one and depends upon the defendant's level of comprehension and communication. The fitness to plead criteria have thus developed largely in relation to individuals with sensory impairment and learning disability, with communication and cognition being the basis for insanity on arraignment. The current validity of the Pritchard criteria has been expressly supported by Lord Justice Keene and approved by the English Court of Appeal in R v M (2003): "That passage from the address to the jury by Baron Alderson in Pritchard has been endorsed subsequently in a number of authorities".

An additional criterion to the Pritchard test was added in the case of $R \vee$ Davies (1853), namely that of being capable of instructing legal advisors. This case was also the first to recognise that impairments arising from psychotic illnesses could affect fitness to plead. Davies was an elderly man charged with murder, who stood silent when asked to plead. There was no question of intellectual impairment, and the judge asked the jury to determine if the mental illness was genuine, basing their decision on the prisoner's appearance and behaviour. Davies was felt to be "mad" by the jury, and he was judged unfit to plead. This early distinction between the learning disabled having sufficient understanding to conduct a defence, and the mentally ill being sane enough to instruct legal advisors, has since been lost. Instead, the additional criterion that a defendant must be "capable of properly instructing his counsel for his defence" has been appended to the Pritchard criteria.

In $\mathrm{R} \vee \mathrm{V}$ Harris, a prisoner attempted to commit suicide by cutting his throat. He was unable to read or write, but his hearing was unimpaired. His self-inflicted injury rendered him unable to speak. The jury found that he was sane and able to plead, but that he was at that time unable to give proper instructions for the preparation of his defence. A plea of not guilty was entered, and the case adjourned to allow him to recover and make adequate preparations for his defence.

The adoption by LCJ Parker in R v Podola (1960) of Baron Alderson's direction to the jury in Pritchard, has made $R \vee$ Pritchard the leading case in the fitness to plead case law. Guenther Podola was arrested on charges of blackmail, but escaped by shooting and killing a policeman. When subsequently arrested, he was knocked unconscious when police broke into his hotel room, and he claimed that this incident made him amnesic for the events surrounding the homicide, thereby preventing him from instructing his legal advisors so as to make a proper defence. The jury did not believe that the amnesia was genuine, but the Home Secretary referred the case to the appellate Court for guidance on the issue of burden of proof. The Court of Appeal ruled that even if the amnesia had been genuine, Podola would still have been fit to plead because loss of memory did not make one unfit in terms of the Pritchard criteria.

The word 'comprehend' in the Pritchard criteria was held to mean no more than 'understand' in $\mathrm{R} v$ Podola (1960), with the resulting emphasis being upon understanding of the proceedings. $\mathrm{R} \vee$ Wheeler (1852) clarified that in order to be fit to plead, the accused must be able to appreciate the difference between a plea of "guilty" and "not guilty". In the case of R v Douglas (1885), the defendant persisted in pleading in spite of his counsel's admission that he was unfit to plead. He was finally allowed to plead, and was found guilty but insane.

There has not been much judicial guidance with regard to the forms of mental illness that would be sufficient to render an accused unfit to plead. In $R v$ Roberts (1954), Devlin J accepted that "defects of the senses", whether or not combined with a "defect of the mind", may render a person unfit to plead. Importantly, Devlin $\mathrm{J}$ ruled that the case against Roberts, who was a 'deaf-mute', should be heard even though it was accepted by both sides that there was no means of communicating with the accused, and the prosecution were pressing for a determination of fitness to plead first. Devlin J warned of "the grave injustice of detaining as a criminal lunatic a man who was innocent". In complete contrast, in R $v$ Benyon (1957) it was stated that "if the Court is aware of the fact that there is a preliminary issue whether the person charged before the court on an indictment is insane so that he is unfit to be tried, it is the duty of the Court to see that that issue is tried".

In R v Robertson (1968), the Pritchard test was said to be one which had been confirmed and followed "over and over again". Robertson was a seaman for believed that his crew were trying to poison him. He was charged with a murder that he readily admitted to, and 
suffered from a paranoid illness that made the Crown question whether he was unfit to plead on the basis that he could not properly defend himself. Medical evidence for the Crown stated that Robertson's "delusional thinking might cause him to act unwisely or otherwise than in his own best interests". The jury found him unfit to plead. However, on appeal, the Court of Appeal stated that "the mere fact that the appellant was not capable of doing things which were in his own best interests was insufficient ground for a jury to return a finding of disability".

In $R \vee$ Berry (1977), it was stated that "a high degree of (mental) abnormality does not mean that the man is incapable of following a trial or giving evidence or instructing counsel and so on". In this case, Berry, who suffered from paranoid schizophrenia, had the finding of unfitness overturned as the judge had not directed the jury to consider the effect that his disorder would have on his ability to comprehend the proceedings.

Case law has also clarified the issue of burden of proof. The question of fitness to plead can be raised by the defence or the prosecution, or indeed the judge, with the burden of proof resting on whichever party raised the issue. The criminal standard (of beyond reasonable doubt) is set for the prosecution ( $R \vee$ Robertson 1968 \& Home Office Circular 93/1991), and the civil standard (on the balance of probabilities) for the defence ( $R \vee$ Podola 1960).

\section{PROCEDURE AND DISPOSALS}

While the criteria for defining fitness to plead were clarified through early case law, the procedure for determining fitness to plead has been laid out in statute. Following the Criminal Lunatics Act (1800), unfit to plead defendants were found "insane upon arraignment" and detained indefinitely. Those fit to plead but where the defendant's actions were a product of their insanity were found "guilty but insane" and again detained indefinitely. The House of Lords in $R v$ Felstead (1914) clarified that a verdict of "guilty but insane" did not amount to a conviction. This important juncture, where both unfit to plead defendants, and those fit to plead and found to have committed the act while insane, were both classed as "criminal lunatics" and disposed of similarly, has led to continued legal confusion between these two distinct groups of defendants.

Under the Criminal Lunatics Act (1884), if a person detained as "insane on arraignment" became sane, the
Secretary of State could order him or her to be remitted to prison to be dealt with according to law. Presumably those termed as "deaf-mutes" could also be remitted to prison for trial if communication subsequently became possible due to further education. The 1884 Act also enabled a prisoner, where certified to be insane while awaiting trial, to be transferred directly to an asylum by a warrant from the Secretary of State. However, the official view for serious offences remained for the patient's insanity to be decided by the verdict of a jury. The "insane on arraignment" phrase was gradually substituted for the term "unfit to plead" as insane on arraignment captured those unfit to plead and stand trial, as well as those who were insane at the time of the alleged offence (Trial of Lunatics Act 1883). However, in $\mathrm{R} v \mathrm{MacHardy}$ it was held that a verdict of unfit to plead does not amount to a conviction, and consequently there is no right of appeal under Section 3 of the Criminal Appeal Act (1907) (Criminal Appeal Reports 1911).

The arrangements set in place by the Criminal Lunatics Act (1800) retained a stable position in law until the advent of the Criminal Procedure (Insanity) Act (1964). Prior to 1964, the Atkin Committee on Insanity and Crime (1925) heard evidence concerning unfitness to plead, and made the sole recommendation that evidence from two doctors should be required for a fitness to plead hearing. The Royal Commission on Capital Punishment (1953), and rejected advice that anyone who was insane or mentally defective should on that basis alone be declared unfit for trial. The Mental Health Act (1959) provided alternative options for dealing with the mentally disordered defendant, such as hospital treatment orders, thereby allowing potentially unfit to plead defendants to be diverted from the criminal justice system in large numbers. ${ }^{2}$

Following the report of the Criminal Law Revision Committee, the Criminal Procedure (Insanity) Act $(\mathrm{CP}(\mathrm{I}) \mathrm{A})$ was passed in 1964. There were four important procedural matters established by the $\mathrm{CP}(\mathrm{I}) \mathrm{A}$. First, that determination of the issue of fitness to plead may be postponed until the opening of the case for the defence if it was expedient, and in the interests of the accused, to do so. Second, once a defendant was found to be "under disability" they were to be admitted to a hospital specified by the Secretary of State and treated as if he or she were admitted

\footnotetext{
${ }^{2}$ Diversion through the hospital treatment order route is only available at a relatively late stage, namely post-conviction (for most)
} 
under Sections 60 and 65 of the Mental Health Act (1959) (hospital order with restrictions unlimited in time). Third, if the patient subsequently became fit to plead, the Act allowed for remission back to prison to await trial, at the discretion of the Secretary of State, after consultation with the responsible medical officer. Fourth, the CP(I)A introduced a mechanism to allow an accused to appeal against a finding of disability. However, the Criminal Law Revision Committee declined to recommend any change to the criteria for fitness to plead, stating that the decision was best left to the courts.

The fitness to plead criteria and procedure next came under serious scrutiny from the (Butler) Committee on Mentally Abnormal Offenders (1975). The Butler Committee, chaired by Lord Butler of Saffron Walden, criticised the current procedures which only allowed determination of the issue by Crown Court jury and not magistrates courts, that the evidence from two doctors was not mandatory despite being agreed, and that there was insufficient emphasis on legal representation. The Butler Committee also recommended the replacement of the term "unfit to plead" with "under disability in relation to trial", and proposed that the reference to challenging a juror should be removed from the fitness to plead criteria. Of key importance, the Butler Committee suggested the introduction of a "trial of the facts" if recovery of fitness did not occur within six months, in order to protect those who were not guilty. Finally, the Committee recommended introducing a range of disposal options, in place of the mandatory hospital order with restrictions.

The fierce criticisms contained within the Butler Committee report, together with a few highly publicised cases, led to a the drafting of a Private Member's Bill which eventually reached the statute books in the form of the Criminal Procedure (Insanity and Unfitness to Plead) Act (CPA) (1991). The CPA was a short Act which amended some parts of the CP(I)A (1964). The trial of the facts was introduced by the CPA following the case of Valerie Hodgson, who had mental health problems and confessed to the murder of her father. Ms Hodgson was found to be unfit to stand trial, and was committed to a mental hospital where she remained for a long period before fresh evidence materialised that suggested someone else had murdered her father. Section 2 of the CPA introduced a trial of the facts procedure to ensure that unfit defendants could be acquitted outright if it could not be proved that they had done the act charged as the offence. The jury had to be satisfied that the accused did the act or made the omission charged against him before the matter could proceed to disposal. The issue of fitness to plead and the trial of the facts could be tried by separate juries, with the issue of fitness to plead being considered at any time up to the opening of the defence case. Evidence from two medical practitioners, one of whom must be approved under the Mental Health Act (MHA) (1983), was made a requirement.

The CPA also gave the judge much broader discretion in respect of disposal options, with potential for absolute discharge, guardianship order, supervision and treatment order as well as the existing admission order with or without restrictions. Guardianship orders and admission orders could only be made if the relevant conditions in the Mental Health Act (1983) were met. Supervision and treatment orders included supervision by probation or social services, and if appropriate, medical treatment as directed by a specified medical practitioner. However, for offences where the sentence was fixed by law, the only disposal available remained an admission order with a restriction order without limit of time. The only offence for which the sentence is fixed by law is murder, and thus this provision represented a mandatory disposal in cases of murder for those found either unfit to plead or not guilty by reason of insanity. The CPA also gave powers to the appellate courts to substitute verdicts of "not guilty by reason of insanity" or "unfit to plead", and then to apply one of the four options for disposal. Once the defendant had been remitted for trial, the CPA removed the requirement for return to prison. ${ }^{3}$

The mandatory disposal of an admission order with restriction order when an unfit to plead defendant is charged with murder led to concerns (Kerrigan 2002) that this may violate Article 5 of the European Convention on Human Rights (ECHR) (1950). This was because a finding of unfitness to plead based on the Pritchard criteria did not necessarily conform to the essential requirements for detention under Article $5(1)(e)$, specifically that:

i. the defendant is reliably shown on the basis of objective medical expertise to have a true mental disorder;

\footnotetext{
${ }^{3}$ The CPA introduced the possibility of remission to the court of trial, prison or remand centre, when the Secretary of State was satisfied that a previously unfit defendant who had received an admission order could now properly be tried.
} 
ii. the disorder is of a kind or degree warranting compulsory confinement; and

iii. the disorder must persist throughout the detention.

As has already been mentioned, defendants could be found unfit to plead on the basis of a number of deficits, such as sensory impairment, learning disability, and physical illness that would not justify detention under the criteria in the Mental Health Act (1983) or Article 5(1)(e) of the ECHR.

Further changes were made to the fitness to plead procedure in the Domestic Violence, Crime and Victims Act (DVCVA) (2004). Firstly, findings of unfitness to plead were no longer to be made by a jury, but by the judge alone. Secondly, the DVCVA removed guardianship as a possibility for disposal of an unfit defendant, leaving three options. The hospital order was made identical to the one in the Mental Health Act (1983), to align hospital-based disposals with the regime of the Mental Health Act. This change ensured that only those unfit to plead defendants who also fulfilled the criteria for detention under the Mental Health Act could receive a hospital disposal, thereby preventing breach of Article 5 of the ECHR. In the case of unfit defendants charged with murder, where the defendant satisfied the criteria and the Court had the power to make a hospital order, the hospital order was to be accompanied by a restriction order. Following a finding of unfitness, the DVCVA also provided extension of the powers to remand a defendant for a report (under section 35 of the MHA (1983)), or for treatment (section 36), and to make an interim hospital order (section 38).

\section{RECENT CASE LAW}

The trial of the facts procedure was introduced in the CPA, and ensures that the evidence against the defendant is tested to some degree. Once it has been established that the defendant is unfit to plead, the trial "shall not proceed further", and a jury must determine whether they are satisfied that the defendant "did the act or made the omission charged against him as the offence". This utilises the same wording as the Trial of Lunatics Act (1883), with regard to the procedure for determining the special verdict of not guilty by reason of insanity. There has, however, been uncertainty about whether this consideration should include the mental element of the offence, namely mens rea.
The Butler Committee, which first recommended a trial of the facts procedure, proposed that the jury should return a verdict of not guilty if they were not satisfied that the defendant "did the act with the necessary mental state", thereby clearly of the view that an acquittal should follow in the absence of proof of mens rea. However, during the passage of the Bill that became the CPA, the government stated that "it would be unrealistic and even contradictory where a person is unfit to be tried properly because of his mental state, that the trial of the facts should nevertheless have to consider that very aspect" (Hansard $186 \mathrm{HC}$ ). The Home Office circular accompanying the CPA stated that it was not intended that mens rea should be taken account of during trial of the facts (Home Office Circular 93/1991).

In R v Egan (1998), the Court of Appeal held that the "the act" required "proof of all the ingredients of what would otherwise be an offence", which would appear to include mens rea. In a subsequent case, the Court of Appeal was faced with a case where the defendant was accepted to be legally insane at the time of the alleged offence. The jury therefore had to decide whether he "did the act or made the omission charged", and the trial judge felt bound by the R $\vee$ Egan ruling requiring all elements of the offence to be proven. Psychiatric evidence suggested that the defendant would have been unable at the material time to form the requisite intent, and the defendant was thus acquitted. This unfortunate situation arose because insanity prevented conviction, but also allowed the defendant to avoid the special verdict. The Court of Appeal found that the trial judge was not bound to follow Egan, and that there was no authority cited for the propositions of the court in Egan, which also had no application to cases of insanity (Attorney General's Reference 1999).

It is submitted that the Court of Appeal was correct in its clarification of the procedure with regard to insanity, where insanity could be based on the absence of intent at the time of offence. It therefore seems unsurprising that mens rea would be irrelevant to determination of whether the defendant did the act or omission. However, the Court of Appeal again compounded the statutory error of conflating the two issues of fitness to plead and insanity, regarding them as "inextricably linked". Therefore, while R v Felstead provided authority for the judgment that Egan was "decided per incuriam" there is no authority stated for dismissing the relevance of mens rea in a case of fitness to plead. 
The Courts further explored the mental element in the case of $R \vee$ Antoine (2000). The trial judge, following Egan, stated that the Crown had to prove both actus reus and mens rea. In the Court of Appeal, Bingham CJ shared the doubts expressed in the Attorney General's Reference case about the necessity of proving mens rea. Lord Hutton in the House of Lords drew the distinction between the words "committed the offence" in the Criminal Lunatics Act (1800), and the words "did the act" in the Trial of Lunatics Act (1883), deducing that the statutory choice of the word "act" therefore did not include intent. The House of Lords therefore overruled the decision in Egan that the "act" included consideration of the mental element, instead introducing similar requirements for both unfitness cases and insanity cases with regard to demonstrating the defendant "did the act or made the omission".

$R \vee$ Antoine (2000) also clarified that the defence of diminished responsibility was not available. The defendant had been charged with murder, been found unfit to plead, but was not permitted to rely on the defence of diminished responsibility in the course of the trial of the facts. The Court of Appeal stated that the defence of diminished responsibility applied only to a person who "but for this section would be liable to be convicted of murder", and as a finding of unfitness prevented the trial from proceeding, the accused was no longer liable to be convicted of murder and the section 2 defence was inapplicable.

$\mathrm{R} \vee \mathrm{H}$ (2001) explored whether the trial of the facts procedure for an unfit defendant constituted a fair hearing, compliant with Article 6 of the ECHR. $\mathrm{H}$ was accused of two counts of indecent assault, and was found unfit to plead. It was contended that the defendant did "not understand the concept of guilt and could not comprehend the evidence, so he would be unable properly to defend himself". The House of Lords held that the trial of the facts procedure was compatible with the ECHR Article 6 right to a fair trial, on the basis that the criminal trial procedure was halted after a finding of unfitness, with no possibility of conviction, determination of guilt, or punishment as a disposal.

$R$ v Heather Grant (2001) considered the availability of the defence of provocation during the trial of the facts. The Court of Appeal ruled that the determination of actus reus under section 4A of the CP(I)A (1964) did not allow the determination of issues relating to mens rea. It was felt that provocation should be considered part of the mens rea, not the "act" and therefore could not be considered in the trial of the facts. It was contended that the mandatory disposal for cases of murder where the defendant was found unfit to plead, may result in arbitrariness which potentially breached Article 5(1)(e). The Court of Appeal ducked the issue due to available evidence justifying detention, stating that this was a difficult issue where Parliament may have carried out the requisite balancing exercise. However, in view of this potential breach of the ECHR, Government shortly afterwards introduced the DVCVA to amend the disposal options available in cases of murder.

The issue of what to do with defendants who regain fitness to plead during their trial has caused some difficulty. In R v Omara (2004), the defendant was found unfit to plead but medical evidence was presented to the Court prior to the trial of the facts that suggested that he had recovered fitness to plead. The judge felt that he had no option but to proceed to the trial of the facts. The Court of Appeal recognised this 'lacuna' in the law, and supported the view that it may have been unlawful to proceed to a trial of the facts if the defendant was, or may have been, fit to plead and stand trial.

The procedure for unfit defendants who regain fitness was clarified in Hasani $v$ Blackfriars Crown Court (2005). It was ruled that where an unfit defendant becomes fit prior to the trial of the facts or disposal of the case, the judge should carry out a second fitness to plead hearing.

The Court of Appeal ruled in R v Borkan (2004) that the court need only consider the issue of fitness to plead if there is medical evidence suggesting that the defendant may be unfit. In that case, a psychiatrist had presented an opinion to the Court that Borkan was fit to plead. However, bizarre behaviour by the defendant in the courtroom led to the trial being abandoned. Another psychiatric assessment suggested that the defendant was not unfit to plead, and further adjournments to arrange medical assessments were refused. The Court of Appeal upheld the judge's decision, stating that all available medical evidence suggested that the defendant was fit to plead. However, this case does tend to question the validity of the Pritchard criteria, as Borkan was rapidly transferred to hospital after conviction under section 47 of the MHA (1983), which leads one to question whether he could have received a fair trial or whether the Pritchard criteria adequately identify mentally ill defendants.

The inadequacy of the fitness to plead process was exposed in R v Norman (2008). The defendant was 
found unfit to plead by a judge, but the time between Norman's arrest and the final disposal was over 17 months. The defendant spent over 12 months in prison before being finally transferred to a hospital. Thomas $\mathrm{LJ}$ issued stark criticism of the delay in this case, and lack of clear explanation for Norman's lengthy incarceration in prison, stating that fitness to plead was "an area of some difficulty where serious problems can arise". To prevent such delays in future, the Court declared that such cases "need very careful case management to ensure that full information is provided to the Court without delay". It was also stated clearly that it was the Court's duty, once a defendant was found unfit to plead, to consider who would be the best person appointed by the Court to put the case for the defence. The Court felt that this was a quite different responsibility to that of an advocate who could take instructions from a client. Finally, this case highlighted the lack of legislative provision for ordering a re-trial of the facts once a defendant has been found unfit to plead.

\section{THE MAGISTRATES COURTS}

All of the procedures and case law outlined above relate to the determination of fitness to plead in the Crown Courts. However, all criminal offences commence in the Magistrates Courts, with the overwhelming majority proceeding no further within the criminal justice system. There is no statutory procedure governing the determination of fitness to plead in Magistrates Courts. However, if the Magistrates Court is faced with a defendant who is apparently unfit to plead, it has a number of possible options to resolve the situation. ${ }^{4}$

Firstly, the Crown Prosecution Service may choose to discontinue legal proceedings if it is felt that the accused person's mental health outweighs the "interests of justice". This mechanism could be combined with admission of the person to hospital under a civil section of the Mental Health Act (1983). If however, prosecution remains in the public interest, the defendant could be transferred to hospital under Part III of the MHA (1983) while criminal proceedings continue. Section 35 of the MHA (1983) allows transfer to hospital for assessment pre-trial, and section 48 of the MHA (1983) allows transfer to hospital of an unsentenced prisoner for urgent treatment. The Section

${ }^{4}$ It should be noted that indictable offences and "either way" offences where the defendant appears unfit, will be sent up to the Crown Court
48 route would allow treatment of a mental disorder, with the aim being restoration of fitness to plead, before returning to Court for trial.

However, if the defendant's mental disorder is resistant to treatment, or it is not envisaged that fitness to plead will be restored by a period of treatment in hospital, the Magistrates Court might consider making a hospital order without recording a conviction. This statutory provision, in Section 37(3) of the MHA (1983), makes no reference to fitness to plead, but requires the Court to be satisfied that the accused did the act or made the omission charged. LCJ Lane termed this an "unusual power" that "would usually require the consent of those acting for the accused if he is under a disability so that he cannot be tried" ( $\mathrm{v} v$ Lincolnshire 1983). This authorises a pragmatic, even paternalistic, approach from defence counsel, at a time when the defendant may not be fit to give instructions to their legal representatives. Going down this path will avoid conviction, but necessitate hospital admission, and remove the possibility of returning to Court if the defendant regains fitness to plead. This is a significant legal responsibility, and without the safeguards of the Crown Court having to consider who might be best suited to act as the defendant's legal representative.

The procedure to be followed for defendants unfit to plead in the Magistrates Court has been clarified through recent case law. In 2001, P, a juvenile with a history of mental health problems and learning difficulties, was charged with harassment and criminal damage ( $R$ (on the application of $P) \vee$ Barking Youth Court 2002). Evidence from a psychologist suggested that $P$ was unfit to plead, but the justices found $P$ fit to stand trial. On judicial review, it was determined that the justices had followed a procedure similar to that required in Crown Court proceedings. However, in Magistrates Court, the justices should have determined if the accused did the act charged, and adjourned for a medical report if felt appropriate, prior to making an order under section 37 of the MHA (1983) for hospital or guardianship order without convicting the defendant.

Another case clarified that the common law defence of insanity can be relied upon in the Magistrates Court (R (Surat Singh) v Stratford Magistrates Court 2007). This interlocutory appeal determined that Section 37(3) of the MHA (1983) was applicable both where the accused was unfit to stand trial or raises the issue of insanity. Blouet v Bath \& Wansdyke Magistrates Court (2009) was a judicial review of the decision of the district judge not to order a fact-finding exercise rather 
than a trial. LJ Goldring stated that, if the Court is of the opinion that an inquiry ought to be made into the physical or mental condition of the accused prior to disposal of the case, the district judge should first ensure that there was up-to-date medical evidence available. Then, if there was a possibility of a Section 37(3) order being made, the judge should examine the issue of whether the accused did the act or made the omission charged. If an adjournment for further reports is required, then this is what should happen. However, if no adjournment is required, the matter could proceed under Section 37(3) immediately.

Therefore, there are no formal procedures in the Magistrates Court to address fitness to plead compared to the Crown Court. Instead, there are mechanisms available to avoid addressing the issue. Diversion of mentally disordered defendants at an early stage of the criminal justice pathway is commendable, in order to provide prompt medical assessment and treatment, and reduce prosecution where this is not in the public interest. By not addressing the issue of fitness to plead in the Magistrates Courts formally, however, there is likely to be an increased possibility of not identifying many unfit defendants. In addition, certain provisions and safeguards available in the Crown Courts are not available in the lower Courts, such as the Crown Court deciding appropriate counsel for the unfit defendant, and the requirement for a trial of the facts prior to disposal. This clearly introduces a two-tier system of standards and legal safeguards, which is not ideal. An inability to carry out any of the functions which constitute the criteria for being fit to plead require procedures and safeguards in place which should not vary dependent on where the case is being heard.

\section{COMPARISON WITH OTHER JURISDICTIONS}

\section{United States}

In the United States, the legal comparison to English law's fitness to plead is "competency to stand trial". As in England, this has been developed as a concept mainly through case law, beginning with influential decisions in the $19^{\text {th }}$ century. In Dusky v United States (1960), the Supreme Court stated that it was not enough for the district judge to find that the defendant is orientated to time and place and has some recollection of events. Dusky was a young man with schizophrenia who was charged with kidnapping after he assisted two teenagers in raping a 16-year old. The Court held the test for competency to be that the defendant "has sufficient present ability to consult with his lawyer with a reasonable degree of rational understanding - and whether he has a rational as well as a factual understanding of the proceedings against him". In Drope v Missouri (1975), the Supreme Court expanded on this, stating that a person whose mental condition is such "that he lacks the capacity to understand the nature and object of the proceedings against him, to consult with counsel, and to assist in preparing his defence may not be subjected to trial". This ruling makes no mention of rational understanding, which may have led to the reaffirmation in Godinez v Moran (1993) that competency to stand trial focused on whether the accused had a rational understanding of the proceedings and the accused's capacity to assist counsel. This case also importantly determined that there were no distinctions between competence to stand trial, competence to waive counsel, and competence to plead guilty.

The emphasis has been on two functional abilities: the cognitive capacity to comprehend relevant legal concepts and procedures, and the volitional element of being able to use such information appropriately in the legal environment to assist in one's defence (Miller 1994). In practice, this often boils down to a requirement for the defendant to acquire relatively detailed knowledge of the judicial system and its relevance for his/her defence. As with Pritchard's criteria, the US standard refers only to the cognitive aspects of mental functioning, and makes no specific reference to other indicators of psychopathology such as affective symptoms or psychosis. The Dusky test is all-or-nothing, as with the Pritchard test. There are some key differences, however, with the Pritchard criteria not encompassing "rational understanding", and no requirement for the defendant to make decisions in the trial process that are in his/her best interests. Although there has been some recent suggestion that being able to understand and reply rationally to the indictment is "obviously a relevant factor" ( $R \vee$ Friend 1997), there has been no further judicial determination on the meaning of the word "rationally".

A number of studies in the US have evaluated the cohort of defendants found incompetent to stand trial. One survey estimated that $50 \%$ of incompetent patients in a state hospital would never be released (Hess and Thomas 1963), with another finding that more incompetent patients left hospital by dying than all other avenues combined (McGarry 1971).

In Jackson v Indiana (1972), the US Supreme Court ruled that individuals incompetent to stand trial could 
not be held in hospital for an "unreasonable" length of time. This ruling has resulted in many more incompetent patients being returned to Court for trial, with those who remain incompetent being detained on a civil order or released. A subsequent national survey found that the average length of stay in hospital for individuals incompetent to stand trial was approximately six months (Steadman et al. 1982).

\section{Australia}

The criteria applied in Australia for fitness to plead are "whether the accused, because of mental defect, fails to come up to certain minimum standards which he needs to equal before he can be tried without unfairness or injustice to him" (R v Presser 1958). Smith $\mathrm{J}$ proceeded to give a detailed list of the minimum standard required for fitness, including being able to understand the charge, being able to plead to the charge and to exercise the right of challenge, to understand generally the nature of the proceeding, to be able to follow the course of proceedings, to be able to understand the substantial effect of any evidence, and to be able to make his defence by giving any necessary instructions to his counsel and by giving evidence to the Court if necessary. The focus is therefore on capacity for understanding, ability to make decisions, and communicating to the Court or legal representatives. There is no explicit requirement for rationality in decision-making, although this could be argued as being implicit within Smith J's explanation.

\section{Canada}

In Canada, the Criminal Code allows the postponement of a criminal trial if an accused is considered to be unfit if, because of a mental disorder, the defendant is unable to understand the nature and object of the proceedings, understand the possible consequences of the proceedings, or communicate with counsel. The focus is again on understanding and capacity for communication, with no requirement for rationality. In R v Taylor (1992), a defendant who suffered from paranoid schizophrenia was initially found unfit to stand trial because his paranoia led to mistrust of his counsel, impairing him of the ability to instruct counsel rationally or to communicate with counsel. The Court of Appeal however, overturned this decision, stating that the presence of delusions did not imply unfitness to plead unless the delusions distorted the accused's rudimentary understanding of the criminal justice process. The appellate Court stated that the ability to conduct a defence and to instruct counsel was limited to being able to recount the necessary facts to counsel.

\section{New Zealand}

Fitness to plead provision in New Zealand is articulated in section 108 of the Criminal Justice Act (1985), which states that a person is "under a disability" if, because of mental disorder, he or she is unable to plead, unable to understand the nature of purpose of the proceedings, or unable to communicate adequately with counsel for the purpose of conducting a defence. Adequate communication, as described by Heron J, implies consideration of the quality of the accused's communication as well as the physical possibility of communication ( $R \quad v$ Carrel 1992). Rationality of decision-making has, however, been explicitly mentioned in New Zealand case law as an essential part of fitness to plead ( $R \vee$ Owen 1964).

\section{Scotland}

In Scotland, a broader interpretation of the fitness to plead criteria, linked to the undefined concept of insanity, has led to a much higher frequency of unfitness finding. Research has demonstrated a tenfold increase in frequency of unfitness determinations in Scotland, compared to England and Wales, accounting for nearly half of all mental health admissions ordered by the Court (Chiswick, Mclsaac and McClintock 1984). The Scottish Law Commission (2004) proposed that unfitness be defined by a defendant being "incapable, by reason of mental or physical condition, of participating effectively in a trial". The Scottish concept of "insanity in bar of trial" will be reformed into "unfitness for trial" through Part 7 of the Criminal Justice and Licensing (Scotland) Bill (2009), which has recently been introduced into Parliament. The criteria, as currently proposed in the Bill for determining unfitness, are essentially similar to the Pritchard criteria.

Overall, it appears that other jurisdictions apply broadly similar criteria in determining the fitness of a defendant to plead and stand trial. They differ significantly in whether rationality is a key component, with the United States and New Zealand leaning towards this position.

\section{RESEARCH}

There is a lack of quality research into fitness to plead in the UK. Investigations have been mainly limited to retrospective studies and a few case reports. 
Many of the studies have also combined the groups under study, including in the same sample defendants assessed for fitness to plead, and those whose insanity at the time of the alleged offence is being evaluated. The summary below contains data obtained from US research into competence to stand trial, which is similar to the English fitness to plead. However, there are important distinctions between the criteria for these two legal entities, and caution needs to be applied in transferring US findings to the patients and legal system in England and Wales.

\section{Number of Unfit to Plead Defendants}

Between 1900 and 1949, 14\% of those committed to trial for murder were found insane on arraignment (Royal Commission on Capital Punishment 1953). Before the First World War, the average annual number of verdicts of insane on arraignment was 24 male and 6 female cases, amounting to 3 per 1000 males and 9 per 1000 females convicted on indictment (Hamblin Smith 1916). During this period between 1900-1949, an average of 28 men and 12 women were found "guilty but insane" each year, and a further 38 males and 30 females were certified insane while waiting trial. The number of unfit to plead cases was observed to have decreased following the introduction of the plea of diminished responsibility in the Homicide Act (1957). A survey of Home Office files from 1976 to 1988 found an average of 25 findings of unfitness each year (Grubin 1991). There was a further decline in use, with only 63 cases of unfitness to plead in the 5 years from 1987 to 1991. Following the Criminal Procedure (Insanity and Unfitness to Plead) Act (1991) which brought some flexibility of disposal into the process, there was a marked increase in the use of fitness to plead. In the 10 years from 1992 to 2001, the number of unfitness findings rose to an average of 45.2 per year (Mackay 2007). Another piece of research found an average of 66 per year between 1997 and 2001 (Mackay, Mitchell and Howe 2007). As a comparison, there are an estimated 60,000 evaluations of competence to stand trial each year in the United States, with around one-fifth of cases being found incompetent (Bonnie and Grisso 2000).

Grubin's study (1991) of 295 patients found unfit to plead in England and Wales between 1976 and 1988 showed that 135 of this group subsequently regained fitness to plead. However, there was a mean of 10.5 months, and a median of 4 months, between the initial finding that the patient had become fit to plead, and the Responsible Medical Officer advising the Home Office.
Home Office policy was to remit to court only if there were exceptional reasons for doing so, but this was reversed after 1982 so that failure to remit had to be justified. This led to the proportion of unfit to plead individuals eventually returning for trial increasing from $12 \%$ before 1982 to $44 \%$ after 1982 . Those patients who did not regain fitness to plead remained detained for an average of 6 years.

\section{Psychiatric Symptoms and Legal Criteria}

In Grubin's sample, more than half had a primary diagnosis of schizophrenia, with $30 \%$ suffering from mental handicap or brain damage. Only 7 of the 295 individuals were profoundly deaf and unable to communicate, reflecting the discordance between the origin of the fitness to plead criteria, and its current use. In terms of symptomatology associated with unfitness, the most common findings in the mental state were paranoid ideas $(38 \%)$, delusions $(44 \%)$ and thought disorder (47\%). Hallucinations were described in around a third of cases. In the written reports prepared for Court, the criteria most commonly quoted as not being met for fitness to plead were ability to instruct counsel $(71 \%)$, ability to comprehend the proceedings $(52 \%)$ and ability to challenge a juror (37\%).

The Pritchard criteria refer to "sufficient intellect", but fewer than a third of unfit defendants actually have intellectual impairment (Mackay, Mitchell and Howe 2007). Nicholson and Kugler found a prevalence rate of only $6 \%$ for mental handicap in their cohort (Nicholson and Kugler 1991). Studies by Aubrey in 1987 and 1988 have indicated that certain characteristics are common among individuals assessed in the US for competence to stand trial. Specifically, $55 \%$ had a history of inpatient treatment and $48 \%$ had a previous conviction for a serious offence. Assessments of fitness to plead were more common when the alleged offence involved some kind of violence. Rogers et al. (1988) found that they could predict fitness determinations with $71 \%$ accuracy using only information about the defendant's gender, race and age, suggesting possible bias in the evaluation process. In the UK, unfit to plead subjects have been described as male in $88 \%$ of cases, with a mean age of 35.7 years, two-thirds of whom had a previous criminal record (Grubin 1991). The typical demographic profile of individuals in the US who have been found incompetent to stand trial is of low-skilled single males with limited education who have been charged with a violent crime (Steadman 1979).

Roesch et al. (1981) found that $89.7 \%$ of their cohort of unfit defendants were diagnosed with some 
form of psychosis. This is consistent with findings from other studies (Roesch and Golding 1980; Cooke 1969). However, nearly one-third of fit to plead defendants in the Roesch study were also diagnosed with a psychotic disorder, suggesting that psychiatrists considered other factors in addition to psychiatric diagnosis in determining fitness to plead. The link between competence and psychosis has been found to be independent of IQ (Viljoen, Roesch and Zapf 2002). Factor analysis has emphasised the importance of the psychoticism, withdrawal and mania symptom clusters (from the Brief Psychiatric Rating Scale) over depressive symptoms in impairing competence to stand trial (Jacobs, Ryba and Zapf 2008). However, as many as $40 \%$ of defendants with no psychiatric diagnosis were found to be impaired on one or more aspects of legal ability, as measured by the Fitness Interview Test instrument.

Roesch et al. (1981) also looked at observed ward behaviours for this group of patients, and found that unfit defendants were observed to be more preoccupied, verbally abusive, nonverbally hostile in general, and menacing or physically assaultative towards others. They were also viewed as hostile and sarcastic, socially isolated on the ward, laughing inappropriately, engaging in bizarre gestures or postures, talking to themselves, having incoherent or disorganised speech, and being restless.

Nicholson and Kugler (1991) quantitatively reviewed thirty studies that had focused on competent and incompetent defendants, finding strong correlation between a finding of unfitness to stand trial and poor performance on tests assessing legally relevant functional abilities, or the presence of a psychotic disorder. They also found statistically significant associations between a finding of unfitness to stand trial and absence of previous legal involvement, and prior psychiatric hospitalisation.

A prospective evaluation of 479 consecutive referrals to psychiatrists at Court examined individual legal fitness criteria as predictors of unfitness to plead, through detailed clinical examination and a 170-item semi-structured interview (James et al. 2001). Of the 466 cases where sufficient information was available to reach a conclusion on fitness to plead, 80 cases $(17.2 \%)$ were judged unfit to plead. Of these, $10 \%$ failed on one legal criterion alone, $17.5 \%$ on two criteria, $37.5 \%$ on three criteria, $12.5 \%$ on four criteria, $10 \%$ on five criteria and $12.5 \%$ on all six criteria. Interestingly, of the 386 judged fit to plead, 20 of these cases $(5.2 \%)$ failed on at least one legal criterion. The most powerful criterion at predicting unfitness to plead was "ability to follow the proceedings of the trial", correctly identifying $91.25 \%$ of the unfit cases, followed by "ability to instruct a solicitor" with a sensitivity of $90 \%$. The two highest ranking symptoms among unfit defendants were "conceptual disorganisation" and "unusual thought content". Differences in the Brief Psychiatric Rating Scale scores between fit and unfit defendants were significant for psychoticism, hostility and withdrawal, in that order. The researchers concluded that a predictive model incorporated just three issues related to trial (following the trial, instructing a solicitor and understanding details of evidence), and that other factors related to plea and charge could be jettisoned without affecting the performance of the remaining criteria in predicting unfitness, so that the fitness to plead criteria could be simplified without loss of predictive power. No defendant within this case series was judged unfit based on issues concerning charge or plea alone.

\section{Structured Objective Assessment Instruments}

The US has pioneered the development of instruments to measure incompetence to stand trial, improve reliability of evidence provided by clinicians in Court, and to reduce subjectivity and arbitrariness in the assessment process. These have developed from simple checklists, to scripted questions, sentencecompletion tasks, and structured and semi-structured interviews. There has been limited success, despite the creation of around 20 structured objective assessment instruments, suggesting that the legal construct of incompetence cannot easily be reduced to a finite set of operational indicators. Some of the sophisticated tools created, such as the MacArthur Adjudicative Competence Study, are impractical for clinical practice, requiring 2 hours to complete by a highly trained research assistant (Hoge et al. 1997). Although the instruments do not discriminate between the various specific criteria which can indicate unfitness to plead, they do appear to increase the reliability of the overall judgment of unfitness (Macdonald, Nussbaum and Bagby 1991).

In England and Wales, the gold standard for assessing fitness to plead remains a consensus of psychiatric opinion. Only one of the structured objective instruments from the US has been adapted for use in England and Wales, the MacArthur Competence Assessment Tool-Fitness to Plead (Akinkunmi 2002). The instrument was administered to a group of 
prisoners with and without mental illness, and was found to be practical, with good internal consistency and inter-rater reliability. Scores of unfit patients were significantly different from those of fit patients. The tool is not yet routinely used in England and Wales.

\section{CRITICISMS OF CRITERIA AND PROCEDURE}

Under the $\mathrm{CP}(\mathrm{I}) \mathrm{A}$ (1964), being found unfit to plead led to the mandatory and indefinite committal of the accused to a psychiatric hospital, which may have been an entirely disproportionate response to the severity of the alleged offence, as well as inappropriate on diagnostic grounds. This led to significant under-use of the unfit to plead route, except for severe offences. The CPA (1991) provided a range of disposals, allowing the outcome to better reflect the clinical and public-safety needs of the case, and removing a major disincentive for addressing fitness to plead. The CPA (1991) also brought in a mechanism to establish the factual case against the unfit defendant, thereby preventing detention when the evidence is insufficient. Criticism that the procedure outlined in the CPA (1991) allowed detention in hospital which was incompatible with Article 5 of the ECHR has also been countered by the amendments contained in the DVCVA (2004). The statutory changes have amended the procedure to make it more flexible, responsive and consistent with human rights legislation, with a resultant increase in number of defendants found unfit to plead.

The continuing validity of the fitness to plead criteria is questioned by its origins in case law based on sensory impairment and learning disabilities, whereas the majority of its application today is in defendants presenting with psychotic symptomatology in the context of schizophrenia or other enduring psychotic mental illness. The Pritchard judgment itself refers to "sufficient intellect" in articulating the criteria, whilst fewer than a third of unfit defendants actually have intellectual impairment (Mackay, Mitchell and Howe 2007).

There has been insufficient distinction, legally and clinically, between the two concepts of insanity and unfitness to plead. This may have arisen partly because the two findings originally led to the same outcome, being insane within the meaning of Section 2 of the Criminal Lunatics Act (1800) and thereby suitable for detention. Another potential reason for this confusion is that the case law dates back to an era when the term "insanity" included both mental impairment and mental illness.
The mental condition of a person found unfit to plead may subsequently improve such that he may become fit to be tried in the normal way. In England and Wales, the Secretary of State for Justice has power to remit for trial certain unfit defendants who recover fitness to plead. However, this procedure has several serious flaws. Firstly, this process depends largely on the Responsible Clinician alerting the Secretary of State to the recovery of fitness to plead. Research has shown a significant delay between patients being deemed fit to plead by their consultant psychiatrist, and informing the Secretary of State (Grubin 1991). Even though detained patients in hospital have to have their detention reviewed at a Mental Health Review Tribunal on a regular basis, the Tribunal does not have the authority to remit for trial, being able only to make such a recommendation to the Secretary of State. Secondly, this procedure allowing remission for trial is only available to those unfit defendants who receive the disposal of a hospital order with restrictions. Thirdly, this ad-hoc process does not protect against the continued re-prosecution of unfit defendants. Re-prosecution of patients who have been found unfit to plead only rarely takes place, although a number of cases have been identified in Scotland (Chiswick, Shubsachs and Novosel 1990). Prosecution authorities in Scotland have now adopted a policy for considering the re-prosecution of unfit to plead defendants, but in England and Wales, it is left to the Crown Prosecution Service (CPS) to decide in any particular case where fitness is regained, whether it is in the public interest to mount a prosecution. It appears that the CPS rarely, if ever, mounts such prosecutions. This lack of emphasis on remission for trial clearly demonstrates that the current legal provisions are intended to circumvent the process of natural justice, rather than ensure that the accused can be brought back to trial once recovered.

A major criticism of the current fitness to plead criteria is that they are not clearly understood by the medical profession. Psychiatric reports frequently use additional criteria to reach their judgment on fitness to plead, for example, whether the defendant has the ability to give evidence, or whether he or she could understand the charges. Some reports prepared for Court clearly confused the insanity criteria with the fitness to plead criteria (Grubin 1991). Indeed, if psychiatrists applied the criteria strictly, it is likely that a very large number of defendants would be declared unfit to plead. For instance, it is likely that a minority of defendants are aware of their right to challenge a juror, 
even after the Clerk to the Court has informed the defendant of this right. In $40 \%$ of pre-trial reports prepared by psychiatrists, there was no mention at all of fitness to plead, with only one-third of the reports making a statement about fitness to plead which was supported by reference to the legal criteria (Larkin and Collins 1989).

Studies have shown that if defendants were considered to be psychotic, the psychiatrists often made the inference that this made them unfit to stand trial (Roesch and Golding 1980). Nicholson and Kugler (1991) found an association between judgments of unfitness and certain legally irrelevant variables. The study by Plotnick, Porter and Bagby (1998) indicated that psychiatrists focused on the legal criteria in making fitness determinations, but were influenced, under certain circumstances, by information unrelated to the legal criteria. Combined with the deference that Courts place on psychiatric opinion, with juries relying heavily on the evidence of expert witnesses in making a judgment on fitness to plead, this lack of understanding has significant negative implications for the mentally disordered offender population (Hart and Hare 1992; Macdonald, Nussbaum and Bagby 1991).

Although not necessarily a direct criticism of the fitness to plead criteria, there is convincing evidence that clinicians apply the criteria in an inconsistent fashion. Grubin's study (1991) found that significant proportions of psychiatric reports failed to mention certain legal criteria in the evaluation of fitness to plead. Only $10 \%$ of psychiatric reports examined by Mackay and Kearns (2000) took into account all the legal criteria in evaluating fitness to plead, with $14 \%$ simply referring to diagnostic category of mental disorder as evidence of unfitness.

Clinicians also appear to change the threshold of fitness to plead depending on the seriousness of the charge. Rosenfeld and Ritchie found that clinicians required a higher degree of competence for defendants charged with more serious offences, and that the assessment process was not identical for competent and incompetent defendants (Rosenfeld and Ritchie 1998).

The criteria currently used in court in England and Wales to determine fitness to plead have remained unchanged for 150 years. However, there remains a lack of clarity within the medical field around the criteria which, at the simplest level, starts with the number of actual criteria. Some commentators refer to five criteria, and others to six. It is no wonder that, if there is inconsistency surrounding the number of fitness to plead criteria, psychiatric reports to Court fail to systematically and comprehensively address the legal criteria in turn. It appears that, instead of giving an opinion to the Court which addresses each criteria in turn, psychiatrists adopt a global view of fitness that does not translate directly to the legal criteria (Bowden 1995). This kind of global view relies on clinical judgement, which is usually subjective but could be improved to a more structured objective format, which is then moulded to fit the legal criteria. By assessing symptoms first and then inferring unfitness, judgments may be affected by clinicians missing symptomatology, or over-interpreting the significance of symptoms. If this form of decision-making is widespread, then the legal criteria themselves may be ineffective and unsuitable to the application of $21^{\text {st }}$ century medical science.

The legal criteria about fitness have conflated the issues of "fitness to plead" and "fitness to stand trial" within the single construct of being "under disability". It is more or less accepted that the term "fitness to plead", as used in England and Wales, incorporates aspects of fitness to stand trial, but the name itself is misleading and may accentuate the widespread misunderstanding. In addition, one of the largest prospective studies of fitness to plead carried out in England and Wales showed that the most predictive legal criteria were actually related to fitness to stand trial, and that the criteria focusing on ability to entering a plea could be jettisoned without affecting the predictive power of the fitness criteria (James et al. 2001).

The difficulty of expert assessment in the field of fitness to plead has been articulated by the US Supreme Court, which held that there are "no fixed or immutable signs which invariably indicate the need for further inquiry to determine fitness to proceed", and that "a wide range of manifestations and subtle nuances are implicated. That they are difficult to evaluate is suggested by the various opinions trained psychiatrists can entertain on the same facts" (Drope v Missouri 1975). This suggests that the US has seemingly abandoned any attempt to formulate definite indicators of competence to stand trial.

The current process does not incorporate any systematic way of detecting defendants who may be potentially unfit to plead. Although court diversion schemes are becoming more widespread, the vast majority of defendants continue to rely upon untrained 
legal professionals to recognise mental health issues and possible unfitness to plead through routine interaction or the occasional communication of health information. The ONS survey found that $10 \%$ of men on remand have shown signs of a psychotic illness in the previous year (Singleton, Meltzer and Gatward 1998), yet formal findings of unfitness to plead are relatively rare in England and Wales. It appears that a very high threshold has been set for "caseness" of impaired fitness to plead in England and Wales (Vassall-Adams and Scott-Moncrieff 2006).

The fitness to plead criteria predate the Criminal Evidence Act (1898), which allowed defendants in criminal trials to give evidence. Hence Pritchard could not have given evidence on his own behalf, although he would have been expected to conduct his own defence if found fit to plead and unable to afford legal counsel. This major change in the role of the defendant has not been reflected in subsequent case law, or encapsulated within the fitness to plead criteria. Lord Hutton in R v Antoine (2000) stated that careful consideration should be given to whether it is right to call a person to give evidence when he or she has been found to be unfit to plead. Section 35 of the Criminal Justice and Public Order Act (1994) offers protection to defendants where it "appears to the Court that the physical or mental condition of the accused makes it undesirable for him to give evidence". 5 Therefore, legislation provides some protection to defendants with regard to giving evidence, but this important aspect of a fair trial remains excluded from the Pritchard criteria.

A major criticism of the fitness to plead criteria and procedure is that it remains available only to defendants in the Crown Courts, with a separate and non-specific mechanism available in the Magistrates Court. From a practical point of view, the majority of mentally disordered offenders appear only in Magistrates Court, hence the fitness to plead pathway is simply failing to reach the majority of its intended recipients.

The continued suitability of the $19^{\text {th }}$ century Pritchard criteria has been questioned repeatedly over time. Although the Butler committee (1975) reported

\footnotetext{
${ }^{5}$ Section 35 of the Criminal Justice and Public Order Act 1994 states that the Court may draw inferences from the failure of the defendant to give evidence, or his silence in the witness box, except where the defendant's guilt is not in issue, or where it appears to the Court that the physical or mental condition of the accused makes it undesirable for him to give evidence.
}

that "most observers thought the current Pritchard criteria largely worked well", it was recommended that the reference to challenging jurors be dropped as it was no longer relevant. It has already been suggested that the ability to give evidence on one's own behalf be possibly introduced (Gray et al. 2001). There have been several attempts to identify a de novo list of important abilities with relation to fitness to plead, which have only served to demonstrate that the existing Pritchard criteria are far from comprehensive (Melton et al. 1997; Dooley et al. 2006). Whittemore, Ogloff and Roesch (1997) found that competence at one stage of criminal proceedings did not correspond with fitness at all other stages, suggesting the need for a stage-specific approach to assessment. It is increasingly recognised that the construct of fitness may differ in younger people, with degree of cognitive maturity and development of socio-emotional capacity being important to the assessment of fitness, and decision-making ability having greater influence on fitness to plead than factual understanding (Cowden and McKee 1995; Grisso 2005).

The association between fitness to plead, and fitness at other stages of the legal process, such as sentencing and (in the United States) execution, are also somewhat unclear. $R \vee$ Dyson (1831), one of the first cases to consider fitness to plead in England, also acknowledged unfitness at the sentencing stage. Blackstone (1897:23) accepted three reasons for extending the concept of unfitness to the postconviction stage of capital cases, stating that an unfit accused could not be fairly expected to raise facts or argument in mitigation to avoid the death penalty, that there was a lack of deterrent in executing a mentally disordered offender, and that there were concerns about the inhumanity and cruelty of executing a mentally disordered offender.

\section{PROPOSALS FOR REFORM}

The fitness to plead concept and criteria have not undergone significant reform for over 150 years. They have failed to adapt to new roles of defendants and advances in psychiatric concepts. A mechanism created originally to deal with malingerers, sensoryimpaired individuals and those with learning difficulty is now being used mainly for defendants with mental illness.

Fitness to plead is a threshold issue of great importance. However, pragmatism and balance must also be party to the reform of fitness criteria and judicial 
determinations. Formulation of a standard that requires full comprehension of the legal process would result in extremely high rates of unfitness, which would not be in anyone's interest. Setting too low a threshold will result in defendants without the requisite abilities having to undergo criminal trial, potentially breaching their right to a fair trial.

Fundamental to the misunderstanding and misuse of the fitness to plead criteria in England and Wales is the lack of attention afforded to this area by the Courts and Government. The law has not prescribed with sufficient detail what the required standards are for those who are to be tried in its Courts. Whilst the legal system may be relatively content with the criteria as developed through case law, it has singularly failed to acknowledge that the process and criteria are of no use unless understood by, accepted by, and utilised by the medical profession. Current research suggests that the medical experts approach fitness to plead in an entirely different manner, perhaps even applying a different concept of fitness, and simply mould their assessment to fit the legal wording. The significant task ahead is to bring both professions together, to collaboratively define the concept of fitness, the capacities required, and a mutual understanding of wording and process.

The current fitness to plead criteria are focused, unsurprisingly once one considers their origin, on intellect and communication ability. There is little flexibility in considering the fitness of an intelligent and articulate defendant with schizophrenia who suffers from delusions that affect the ability to participate effectively in the trial. Firstly, the fitness to plead criteria should be a two-stage process, with the first test being to establish whether the person has an impairment of, or disturbance in the functioning of, the mind or brain. This brings a primary diagnostic threshold which must be met, and excludes those with just sensory impairment or communication difficulties as this group, in the $21^{\text {st }}$ century, are educated and well capable of assimilating information, weighing up information, making rational decisions and communicating through various alternate means as necessary.

Secondly, there needs to be a realignment of the criteria to apply a functional test to establish whether the impairment or disturbance causes the person to be unable to participate effectively in the trial, through the following criteria:

- $\quad$ sufficient understanding of the charge and consequences of pleas in order to enter a plea
- $\quad$ contributing effectively towards their defence by being able to follow evidence in court, communicate with their lawyer and weigh up information in order to reach balanced and informed decisions

The criterion of challenging a juror should be jettisoned as it does not adequately correlate with the core abilities required to participate effectively in a criminal trial. This criterion is instead largely based on whether the defendant is aware or not of this particular legal right.

The underlying principles behind the fitness to plead concept should be to ensure that criminal defendants are able to participate effectively in their trial, allowing those suffering from mental disorder which may impede in this ability to receive prompt treatment before returning for trial. The objective of returning defendants for trial is proposed as a key principle for the reformed criteria, and one which will drive prompt recognition and treatment of mental disorder and return to the Courts to allow both defendants to legally contest allegations and justice to be served. Articulating a clear objective of remission for trial once fitness is recovered allows defendants the opportunity to challenge allegations in the ordinary way, without discrimination, and will significantly shorten their length of detention in hospital. Although many of this cohort may subsequently be convicted, this provides some clarity to the offender, justice system and health service in assessing risks and predicting needs. The offender can then receive the most appropriate sentence, which may be a hospital order or supervision order with psychiatric requirement.

A clear system needs to be introduced for enabling unfit defendants to return to Court for trial once fitness has recovered, which does not depend upon Responsible Clinicians recognising recovery of fitness, and the Secretary of State determining whether to remit for trial. The applicability of remission for trial should be widened to include all defendants found unfit to plead, not just those who receive a hospital order with restrictions, as at present. Further, clear guidelines need to be in place to prevent re-prosecution of unfit defendants by the CPS, with the emphasis being on treatment and recovery of fitness, following by remission for trial.

The Mental Capacity Act (MCA) (2005) adopts a functional approach in determining a person's capacity to take a particular decision in a particular context. The 
principle of proportionality is clearly embedded in case law concerning the level of capacity required for health care decisions, and this has now been encapsulated in the MCA (2005). There is no similar requirement for greater capacity for complex decisions with regard to standing trial in the criminal Court. Mackay (2007) has observed that the MCA (2005) is "part of a continuing trend to protect the decision-making process of the mentally vulnerable within the civil law". This has been partly extended in criminal law, for example Section 30 of the Sexual Offences Act (2003) protects persons "with a mental disorder impeding choice" from sexual interference, but has yet to influence the fitness to plead law.

The disparity between the civil law test for capacity and the criminal law test for fitness to plead is stark, and clearly discriminates against the criminal defendant. A person who would be deemed incapable of making relatively trivial decisions about his life under the civil law test, might easily be found fit to plead under criminal law and be expected to participate meaningfully at trial. The capacity test includes not only the ability to understanding information, retain information and communicate a decision, but it also incorporates the essential ability of weighing up and balancing available information. The civil law accepts that intelligent and articulate individuals may have an impairment or disorder of mind or brain that may incapacitate them from making certain decisions, and also that individuals with severe and enduring mental illness or mental impairment may still be able to make certain decisions for themselves.

Reform of fitness to plead should articulate a functional approach, identifying specific tasks or requirements, and the cognitive or psychological capacities required to fulfil those tasks. It is clear that the tasks and requirements will vary with the complexities and nuances of the legal case, and hence the level of capacities required will also vary. A reframing of fitness to require "capacities" rather than "abilities" will help to express this functional approach to determination of fitness.

The fitness to plead criteria currently makes no reference to decisional competence, as compared to the MCA (2005). It has recently been suggested that rationality is a relevant factor to understanding and replying to the indictment, although there has been no further judicial analysis on this area ( $\mathrm{v}$ Friend 1997). It has been argued by commentators that cognitive rationality is a fundamental ability, without which an accused cannot properly be said to be fit to stand trial
(Freckleton 1996). Rationality incorporates both inadequate reasoning processes, as in insufficient for the task, and disordered reasoning by virtue of mental disorder. The concept of decisional ability has been proposed in the US as being a key factor in competence to stand trial, with this concept involving the sub-processes of rational decision-making, namely cognitive skills, conceptual abilities and rationality of thought (Bonnie 1992).

Whatever reform the fitness to plead criteria undergo, it is important to improve the quality of assessments performed and presented by the medical profession. Improving quality involves reducing subjectivity and arbitrariness. The application of objective structured instruments will also improve consistency and validity of the assessment process, although this raises the key question of whether the concept of fitness to plead can be reduced to finite operational indicators. As the criteria currently stand, this appears a significant challenge. Reform of the criteria to encompass capacity in certain key skills-sets, flexible to the complexity of decision faced, should be approached with operational indicators at the fore, as legal criteria without operational utility would be meaningless for an issue such as fitness to plead which relies upon multidisciplinary involvement.

Fitness to plead criteria in themselves should not be the sole solution to ensuring the defendants are able to participate effectively in criminal trials. Although English law to date has tended to impose such a high threshold of unfitness that it is reserved only for the most severely disturbed defendants, there is potential for modifications in the trial process to enable a large proportion of defendants to participate more effectively in trial. Even with a lowering of the threshold for fitness to plead, and a more flexible threshold to encompass complexity of decisions and decisional competence, a Court system which responds better to defendants' needs will only serve to improve the basic tenets of natural justice. Anecdotal evidence suggests that, even when medical experts suggest simple modifications to the trial process to enable defendants to participate effectively, these do not occur in practice. The trial of two 10-year-olds Thompson and Venables for the murder of James Bulger was held to breach Article 6 by the European Court of Human Rights, as the young defendants had been denied a fair trial in light of their youth and their lack of understanding of the legal process. Despite special arrangements having been made in the Crown Court, the European Court held that the two youths were highly likely to have been unable 
to follow the proceedings properly or pass information to their lawyers. The criminal justice system needs to demonstrate that it is willing to make modifications where necessary to the trial process to fulfil its responsibilities in ensuring that defendants are able to participate effectively in criminal proceedings.

Finally, the term "fitness to plead" itself may not be particularly helpful. Research suggests that the elements of fitness to plead related to entering a plea are less useful in predicting the ability of a defendant to participate effectively in the trial. It is proposed that a renaming to "fitness to stand trial" may better describe the core abilities required to meet the threshold for fitness, and re-branding the concept will help in enhancing awareness of the reform process.

\section{REFERENCES}

Akinkunmi, A. A. (2002) The MacArthur Competence Assessment Tool - Fitness to Plead: A preliminary evaluation of a research instrument for assessing fitness to plead in England and Wales. Journal of the American Academy of Psychiatry and Law, 30, 476-482

Allen, Kesavarajah \& Moses (1993) A Crim R 376 at para 397

Attorney General's Reference no. 3 of 1998 [1999] 3 All ER 40, page 48

Aubrey, M. (1987) Evaluations of Competency to Stand Trial: Frequency of Repeated Referrals. Journal of Psychiatry and Law, 15, 425

Aubrey, M. (1988) Characteristics of Competency Referral of Defendants and Nonreferred Criminal Defendants. Journal of Psychiatry and Law, 16, 233

Blackstone's Commentaries, Lewis Edition; Rees, Welsh and Co., Philadelphia: 1897, at 23-25

Blouet v Bath \& Wansdyke Magistrates Court [2009] EWHC 759 (Admin)

Bonnie, R. J. \& Grisso, T. (2000) Adjudicative competence and youthful offenders. In T. Grisso \& R. G. Schwartz (Eds.), Youth on trial: A developmental perspective on juvenile justice, p 73-103. Chicago: University of Chicago Press

Bonnie, R. J. (1992) The competence of criminal defendants: A theoretical reformulation. Behavioural Sciences and the Law, $10,291-316$ http://dx.doi.org/10.1002/bsl.2370100303

Bowden, P. (1995) Criminal Proceedings. In Practical Forensic Psychiatry (ed. D. Chiswick and R. Cope), p106-133. Gaskell: London

(Butler) Committee on Mentally Abnormal Offenders. Home Office and Department of Health and Social Security, 1975

Chiswick, D., Mclsaac, M. W. \& McClintock, F. H. (1984) Prosecution of the Mentally Disturbed. Aberdeen University Press, p12

Chiswick, D., Shubsachs, A. P. W. \& Novosel, S. (1990) Reprosecution of patients found unfit to plead: a report of anomalies in procedure in Scotland. Psychiatric Bulletin, 14, 208-210 http://dx.doi.org/10.1192/pb.14.4.208

Cooke, G. (1969) The court study unit: Patient characteristics and differences between patients judged competent and incompetent. Journal of Clinical Psychology, 25, 140-143 http://dx.doi.org/10.1002/1097-4679(196904)25:2<140::AIDJCLP2270250207>3.0.CO:2-J
Cowden, V. L. \& McKee, G. R. (1995) Competency to stand trial in juvenile delinquency proceedings: Cognitive maturity and the attorney-client relationship. University of Louisville Journal of Family Law, 33, 629-660

Criminal Appeal Reports (1911) vi, p 272

Dooley, C., Baker, P., Devonshire, P., Evers, C., Herbert, C. \& Husband, H. (2006) Professional practice board assessment of capacity guidelines group assessment of capacity in adults: Interim guidance for psychologists. The British Psychological Society, April 2006

Drope v Missouri (1975) 420 US 162, 43 L Ed 2d 103, 95 S Ct 896

Dusky v United States (1960) 362 US 402, 4 L Ed 2d 824, 80 S Ct 788

European Convention of Human Rights (1950) Council of Europe

Freckleton, I. (1996) Rationality and flexibility in assessment of fitness to stand trial. International Journal of Law and Psychiatry, 19(1), 39-59

Godinez v Moran 125 L Ed 2d 321, 113 S Ct 2680 (1993)

Gray, N. S., O'Connor, C., Williams, T., Short, J. \& MacCulloch, M. (2001) Fitness to plead: Implications from case law arising from the Criminal Justice and Public Order Act 1994. Journal of Forensic Psychiatry, 12, 52-62

Grisso, T. (2005) Evaluating juveniles' adjudicative competence: A guide for clinical practice. Sarasota, FL: Professional Resource Press

Grubin, D. H. (1991) Unfit to plead in England and Wales, 19761988: a survey. British Journal of Psychiatry, 158, 540-548 http://dx.doi.org/10.1192/bjp.158.4.540

Hale, M. (1971) The history of the pleas of the Crown (Vols 1 and 2). London: Professional Books.

Hamblin Smith, M. (1916) Unfitness to plead in criminal trials. Journal of Mental Science, 62, 763-774

Hansard $186 \mathrm{HC}\left(6^{\text {th }}\right.$ Series$)$ col. 1280,1 March 1991, per John Patten MP, minister of state at the Home Office

Hart, S. D. \& Hare, R. D. (1992) Predicting fitness to stand trial: the relative power of demographic, criminal and clinical variables. Forensic Reports, 5, 53

Hess, J. H. \& Thomas, H. E. (1963) Incompetency to stand trial: procedures, results, and problems. American Journal of Psychiatry, 119, 713-720

Higson, W. D. (1936) Unfitness to plead. Journal of Mental Science (1935) 81: 822-833

Hoge, S. K., Bonnie, R. J., Poythress, N., Monahan, J., Eisenberg, M. \& Feucht-Havier, T. (1997) The MacArthur adjudicative competence study; development and validation of a research instrument. Law and Human Behaviour, 21, 141-179 http://dx.doi.org/10.1023/A:1024826312495

Home Office: Mentally Disordered Offenders: Inter-Agency Working Circular 12/95, London: Home Office 1995

Jackson v Indiana (1972; 406 US 715)

Jacobs, M. S., Ryba, N. L. \& Zapf, P. A. (2008) Competence-related abilities and psychiatric symptoms: An analysis of the underlying structure and correlates of the MacCAT-CA and the BPRS [Electronic version]. Law and Human Behaviour, 32(1), 64-77 http://dx.doi.org/10.1007/s10979-007-9086-8

James, D. V., Duffield, G., Blizzard, R. \& Hamilton, L. W. (2001) Fitness to plead. A prospective study of the interrelationships between expert opinion, legal criteria and specific symptomatology. Psychological Medicine, 31, 139150 http://dx.doi.org/10.1017/S0033291799002901

Kerrigan, K. (2002) Psychiatric evidence and mandatory disposal: Article 5 compliance? Journal of Mental Health Law, July 2002, 130-138 
Larkin, E. P. \& Collins, P. J. (1989) Fitness to plead and psychiatric reports. Medicine, Science and the Law, 29, 26-32

Macdonald, D. A., Nussbaum, D. S. \& Bagby, R. M. (1991) Reliability, validity and utility of the Fitness Interview Test. Canadian Journal of Psychiatry, 36(7), 480-484

Macdonald, D. A., Nussbaum, D. S. \& Bagby, R. M. (1991) Reliability, validity and utility of the Fitness Interview Test. Canadian Journal of Psychiatry, 36(7), 480-484

Mackay, R. D. \& Kearns, G. (2000) An upturn in fitness to plead? Disability in relation to the trial under the 1991 Act. Criminal Law Review, 532-546

Mackay, R. D. (2007) AAPL Practice Guideline for the Forensic Psychiatric Evaluation of Competence to Stand Trial: An English Legal Perspective. J Am Acad Psychiatry Law, 35, 501-504

Mackay, R. D., Mitchell, B. J. \& Howe, L. (2007) A continued upturn in unfitness to plead: More disability in relation to trial under the 1991 Act. Criminal Law Review, 530-545

McGarry, A. L. (1971) The fate of psychotic offenders returned for trial. American Journal of Psychiatry, 127, 1181-1184

Melton, G. B., Petrila, J., Prythress, N. G. \& Slobogin, C. (1997) Psychological evaluations for the Courts: A handbook for mental health professionals and lawyers. $\left(2^{\text {nd }}\right.$ ed.) New York: Guilford

Miller RD. Criminal competence, in Principles and Practice of Forensic Psychiatry. Edited by Rosner R. New York: Chapman Hall, 1994, p 174-197

Mossman, D. Noffsinger, S. G., Asp, P., et al. (2007) AAPL Practice Guideline for the Forensic Psychiatric Evaluation of Competence to Stand Trial. Journal of the American Academy of Psychiatry and Law, 35(Supp), 3-72

Nicholson, R. A. \& Kugler, K. E. (1991) Competent and incompetent criminal defendants: A quantitative review of comparative research. Psychiatric Bulletin, 106, 184-203

Plotnick, S., Porter, J. \& Bagby, M. (1998) Is there bias in the evaluation of fitness to stand trial? International Journal of Law and Psychiatry, 21(3), 291-304 http://dx.doi.org/10.1016/S0160-2527(98)00007-7

R (Hasani) v Blackfriars Crown Court [2005] WEHC 3016 (Admin)

$\mathrm{R}$ (On the application of $\mathrm{P}) \vee$ Barking Youth Court [2002] EWHC 734 (Admin)

R (Surat Singh) v Stratford Magistrates Court [2007] EWHC 1582 (Admin)

R J Bonnie (1993) The Competence of Criminal Defendants: Beyond Dusky and Drope. University of Miami Law Review, 47(3), 539-540

$R$ v Antoine [1999] 3 WLR p 1210

R v Antoine [2000] 2 All ER 208 (HL); [1999] 3 WLR 1204 (CA)

$R$ v Benyon [1957] 2 QB 111 at 114

R v Berry [1977] 66 Cr. App. R. 156 at 158

$R$ v Borkan [2004] EWCA Crim 1642

$R \vee$ Carrel [1992] 1 NZLR 760 at 762

$R$ v Davies [1853] CLC 326

$R \vee$ Douglas [1885] (unreported)

$R \vee$ Dyson (1831) 7 C. \& P. 305, n.

R v Egan [1998] 1 Cr App R 121; [1996] 35 BMLR 103

$R \vee$ Felstead [1914] AC 534

$R$ v Friend [1997] 2 All ER 1012, 1018

$\mathrm{R} \vee \mathrm{H}$ and Secretary of State for the Home Department [2003] UKHL1

R v Harris (1836) 61 J.P. 792

R v Heather Grant [2001] EWCA Crim 2611
$R \vee$ Lincolnshire (Kesteven) Justices ex parte Connor [1983] 1 WLR 335, p338

R v M [2003] EWCA Crim 3452 para 31

$R \vee M, K$ \& $H$ [2001] EWCA Crim 2024

$R$ v Norman [2008] EWCA Crim 1810

$\mathrm{R} v$ Omara, Lawtel, 13 February 2004

$R$ v Owen (No 2) [1964] NZLR 828 at 831

$R$ v Podola [[1960] 1 QB 325, [1959] 3 All ER 418

$R \vee$ Presser [1958] VR 45 at 48

R v Pritchard (1836) 7 C. \& P. 303

R v Rivett (1950) 34 Cr App R 87, para 94

$R$ v Roberts [1954] 2 QB

R v Robertson [1968] 3 All ER 557, [1968] 52 Crim. App. 690

$R \vee$ Steel (1787) 2 Leach 507

$R v$ Taylor [1992] 11 OR (3d) 323

$\mathrm{R} v$ Thomas Jones (1773) 1 Leach 102

$R \vee$ Wheeler [1852] (unreported)

Report of the Royal Commission on Capital Punishment, Hansard, 2 July 1953

Roesch, R. \& Golding, S. L. (1980) Competency to stand trial. Urbana: University of Illinois Press

Roesch, R., Eaves, D., Sollner, R., Normandin, M. \& Glackman, W. (1981) Evaluating Fitness to Stand Trial: A Comparative Analysis of Fit and Unfit Defendants. International Journal of Law and Psychiatry, 4, 145-157 http://dx.doi.org/10.1016/0160-2527(81)90025-X

Rogers, R., Gillis, J. R., McMain, S. \& Dickens, S. E. (1988) Fitness evaluations: A retrospective study of clinical, criminal and sociodemographic characteristics. Canadian Journal of Behavioural Science, 20, 192-200 http://dx.doi.org/10.1037/h0079925

Rogers, T. P., Blackwood, N. J., Farnham, F., Pickup, G. J. \& Watts, M. J. (2008) Fitness to plead and competence to stand trial: a systematic review of the constructs and their application. Journal of Forensic Psychiatry \& Psychology, 19(4), 576-596 http://dx.doi.org/10.1080/14789940801947909

Rosenfeld, B. \& Ritchie, K. (1998) Competence to stand trial: Clinician reliability and the role of offence severity. Journal of Forensic Science, 43, 151-157

Royal Commission on Capital Punishment (1953) 1949-1953: Report. London: HMSO

Scottish Law Commission (2004) Report on Insanity and Diminished Responsibility. Edinburgh, Stationery Office, Annex A: draft Criminal Responsibility and Unfitness for Trial (Scotland) Bill, clause 4

Singleton, N., Meltzer, H. \& Gatward, R. (1998) Psychiatric morbidity among prisoners in England and Wales. London: Stationery Office

Steadman, H. J. (1979) Beating a rap? Defendants found incompetent to stand trial. Chicago: University of Chicago Press

Steadman, H. J., Monahan, J. \& Hartson, E. (1982) Mentally disordered offenders: a national survey of patients and facilities. Law and Human Behaviour, 6, 31-38 http://dx.doi.org/10.1007/BF01049311

Vassall-Adams, G. \& Scott-Moncrieff, L. (2006) Capacity and fitness to plead: The yawning gap. Counsel, 14-16

Viljoen, J. L., Roesch, R. \& Zapf, P. A. (2002) An examination of the relationship between competency to stand trial, competency to waive interrogation rights, and psychopathology. Law and Human Behaviour, 26, 481-506 http://dx.doi.org/10.1023/A:1020299804821 
Walker, N. (1968) Crime and insanity in England, Vol. 1: The historical perspective. Edinburgh University Press, $\mathrm{p} 15$
Whittemore, K. E., Ogloff, J. R. \& Roesch, R. (1997) An investigation of competency to participate in legal proceedings in Canada. Canadian Journal of Psychiatry, 42, 869-875

Received on 11-07-2012

Accepted on 09-11-2012

Published on 13-11-2012

DOI: http://dx.doi.org/10.6000/1929-4409.2012.01.17

(C) 2012 Amar Shah; Licensee Lifescience Global.

This is an open access article licensed under the terms of the Creative Commons Attribution Non-Commercial License (http://creativecommons.org/licenses/by-nc/3.0/) which permits unrestricted, non-commercial use, distribution and reproduction in any medium, provided the work is properly cited. 